\title{
The role of career concerns and workplace friendship in the job embeddedness-retention practices satisfaction link
}

\begin{tabular}{|c|c|}
\hline \multicolumn{2}{|c|}{$\begin{array}{l}\text { Authors: } \\
\text { Ingrid L. Potgieter }{ }^{1} \\
\text { Melinde Coetzee }^{2} \\
\text { Nadia Ferreira }^{1}\end{array}$} \\
\hline \multicolumn{2}{|c|}{$\begin{array}{l}\text { Affiliations: } \\
{ }^{1} \text { Department of Human } \\
\text { Resource Management, } \\
\text { University of South Africa, } \\
\text { South Africa }\end{array}$} \\
\hline \multicolumn{2}{|c|}{$\begin{array}{l}{ }^{2} \text { Department of Industrial } \\
\text { and Organisational } \\
\text { Psychology, University of } \\
\text { South Africa, South Africa }\end{array}$} \\
\hline \multicolumn{2}{|c|}{$\begin{array}{l}\text { Corresponding author: } \\
\text { Ingrid Potgieter, } \\
\text { visseil@unisa.ac.za }\end{array}$} \\
\hline \multicolumn{2}{|c|}{$\begin{array}{l}\text { Dates: } \\
\text { Received: } 12 \text { Jan. } 2018 \\
\text { Accepted: } 02 \text { Mar. } 2018 \\
\text { Published: } 30 \text { Apr. } 2018\end{array}$} \\
\hline \multicolumn{2}{|c|}{$\begin{array}{l}\text { How to cite this article: } \\
\text { Potgieter, I.L., Coetzee, M., \& } \\
\text { Ferreira, N. (2018). The role } \\
\text { of career concerns and } \\
\text { workplace friendship in the } \\
\text { job embeddedness-retention } \\
\text { practices satisfaction link. } \\
\text { SA Journal of Industrial } \\
\text { Psychology/SA Tydskrif vir } \\
\text { Bedryfsielkunde, 44(0), } \\
\text { a1519. https://doi.org/ } \\
\text { 10.4102/sajip.v44i0.1519 }\end{array}$} \\
\hline \multicolumn{2}{|c|}{$\begin{array}{l}\text { Copyright: } \\
\text { (c) 2018. The Authors. } \\
\text { Licensee: AOSIS. This } \\
\text { is licensed under the } \\
\text { Creative Commons } \\
\text { Attribution License. }\end{array}$} \\
\hline \multicolumn{2}{|l|}{ Read online: } \\
\hline 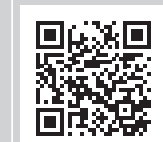 & $\begin{array}{l}\text { Scan this QR } \\
\text { code with your } \\
\text { smart phone or } \\
\text { mobile device } \\
\text { to read online. }\end{array}$ \\
\hline
\end{tabular}

Orientation: The demand for retaining top talent in the highly competitive and turbulent working environment has made retention research relevant and important. A central question in retention research revolves around the psychological factors that drive employees to remain at an organisation.

Research purpose: This research explores the mediating and conditional (moderating) processes underlying the link between employees' job embeddedness and satisfaction with organisational retention practices.

Motivation for the study: Several research studies are available with regard to the association between job embeddedness and retention practices. However, there seems to be a paucity of information available on the psychological process of workplace friendship underlying the job embeddedness-retention practices satisfaction link, as well as the boundary conditions of this process as set by employees' career concerns.

Research design, approach and method: The study followed a cross-sectional, quantitative research design. Data were collected from a convenience sample of $(N=200)$ permanently employed staff members within a South African higher education institution. Moderatedmediation analysis was performed to achieve the research objective.

Main findings: The findings indicated career concerns as important boundary conditions for the psychological (mediating) process of workplace friendship in the job embeddednessretention practices satisfaction link.

Practical/managerial implications: Enhancing work conditions and practices to support the evolving career development needs and concerns of valuable employees may be key to maintaining person-environment correspondence and retaining them.

Contribution or value-add: The findings extend retention theory by adding new insights into under what circumstances employees' job embeddedness positively influences their satisfaction with organisational retention practices. The study provides new evidence of the important role of employees' career development needs in retention theory and practice.

\section{Introduction}

\section{Key focus}

Several recent research studies have focused on the importance of retaining valuable human capital in today's competitive world of work (Deas, 2017; Khaleel, Chelliah, Khalid, Jamil, \& Manzoor, 2016; Stoltz, 2015; Van Dyk, 2012). Higher education institutions are specifically vulnerable to losing their highly qualified staff to the private sector and to other higher education institutions that offer better rewards and benefits (Erasmus, Grobler, \& Van Niekerk, 2015; Samuel \& Chipunza, 2009). For organisations and practitioners, the retention of employees generally alludes to understanding the psychological factors and practices that bind the employee to the organisation and facilitate person-environment correspondence or fit (Döckel, 2003; Stoltz, 2015). The notion of person-environment correspondence (Dawis, 1996; Dawis \& Lofquist, 1993) has become important in the retention literature because it speaks to the mutual needs of employees and organisations. Employees are more satisfied, productive and committed when they perceive a fit between their job and career development needs and work environment conditions and practices, which in turn also addresses the organisation's need to retain highperforming employees in a competitive business environment (Capuzzi \& Stauffer, 2006; Döckel, 2003; Kim, 2017). 
Job embeddedness has emerged as a retention construct that indicates employees' sense of person-environment fit (Johnson, Sachau, \& Englert, 2010). Employees' decision to leave an organisation is not made in isolation but is shaped by the environment in which the individual is embedded (Lee, Mitchell, Sablynski, Burton, \& Holtom, 2004; Mitchell, Holtom, \& Lee, 2001a). Research suggests that employees who are highly embedded in their jobs might choose to stay with an employing organisation even if circumstances are less than ideal (Asgharian, Yusof, YaserMazhari, \& HazratSoltan, 2013). Research has further established retention practices such as training and development opportunities, career development opportunities, job characteristics and supervisor support as positive predictors of employees' job embeddedness (Van Dyk, 2012). Although linear links have been established between job embeddedness and retention practices satisfaction, research on the psychological processes and circumstances under which the link between employees' job embeddedness and retention practices satisfaction is strengthened or weakened is lacking, especially in the higher education environment. The objective of the present research was therefore to explore the mediating and conditional (moderating) processes underlying the link between employees' job embeddedness and satisfaction with organisational retention practices.

\section{Background of the study}

Because person-environment fit theory (Dawis, 1996; Dawis \& Lofquist, 1993) indicates employees' career development needs as central to the interaction between them and the work environment, the present study was interested in exploring the moderating role of employees' career concerns in the job embeddedness-retention practices satisfaction link. Research on person-environment fit also established workplace affiliations as important social support mechanisms in employees' job embeddedness and career development (Jiang, 2017; Ng \& Feldman, 2009). The present research was therefore also interested in exploring workplace friendship as a mediating psychological process in the job embeddedness-retention practices satisfaction link. Although contrasting results were found with regard to the advantages and disadvantages of workplace friendships (Bayes \& Kelly, 1994; Paul, 1994), several research studies confirmed that employees who have high-quality friendships at the workplace were more satisfied with their jobs, which positively influenced their retention (Khaleel et al., 2016; Nielsen, Jex, \& Adams, 2000; Riordan \& Griffethc, 1995). However, research on the mediating role of workplace friendship in the job embeddedness-retention practices satisfaction link is lacking.

Replicating research that suggests employees' job embeddedness and satisfaction with retention practices are important factors in the question of which psychological factors drive employees' intentions to remain at the organisation (Van Dyk, 2012), the present research adds new insights into understanding the job embeddedness-retention practices satisfaction link. Van Dyk's (2012) research was conducted in the ICT environment and treated retention practices satisfaction as predictors of job embeddedness. The current study treats job embeddedness as an explanatory mechanism of employees' satisfaction with retention practices satisfaction in the higher education environment, which makes the study unique. Seen through the theoretical lens of personenvironment fit theory (Dawis, 1996; Dawis \& Lofquist, 1993), the research aims to illuminate the psychological mediating process of workplace friendship underlying the job embeddedness-retention practices satisfaction link, as well as the boundary conditions of this process, as set by employees' career concerns. This approach extends retention theory, and the new insights may help to inform retention practices in the higher education environment.

\section{Trends from the research literature}

Person-environment fit theory (Dawis, 1996; Dawis \& Lofquist, 1993) suggests that the relationship between employees and the organisation is one of mutual responsiveness and that both the person and environment strive to achieve and maintain correspondence with each other. Employees' needs and expectations are primary in their influence on fit. Person-environment correspondence is indicated by an employee's overall job satisfaction; satisfaction with work environment conditions and culture; and satisfaction and fulfilment of career development needs, aspirations and expectations (Capuzzi \& Stauffer, 2006; Dawis, 1996). Employees' skills and career development needs are changeable, along with the evolvement of their selfconcepts (Super, 1990). Adjusting to ever-evolving personal career-life needs, along with changing working conditions and organisational requirements, is therefore inherent to the employees' process of achieving and maintaining personenvironment correspondence. Adjustment subsequently implies that employees' needs and expectations will change over time. Based on the principle of mutual responsiveness, the organisation also has to adjust to the changing needs and expectations of their employees. Satisfaction is core to the process of adjustment and is a consequence of perceived person-organisation correspondence, which leads to job tenure and better job performance (Dawis, 1996).

\section{Satisfaction with retention factors}

Organisational retention practices facilitate employees' intention to stay or to leave an organisation (Döckel, Basson, \& Coetzee, 2006; Netswera, Rankhumise, \& Mavundla, 2005). Research has established that human resource practices, such as compensation and benefit packages and policies, job characteristics (i.e. job autonomy and variety), personal and job-specific training and development opportunities that build employees' competence and need for personal growth, career advancement opportunities and supervisor support and work-life balance policies, foster employees' job embeddedness and commitment to the organisation (Döckel, 2003; Van Dyk, 2012). Employees' overall level of satisfaction with organisational retention practices further significantly predicts their overall sense of job embeddedness 
(Van Dyk, 2012). Seen through the theoretical lens of personenvironment correspondence (Dawis, 1996), organisational retention practices reflect the work culture of the organisation and the attempts made by the organisation to achieve and maintain correspondence with the needs of their employees. As such, employees' overall satisfaction with organisational retention practices will reflect their perception of personenvironment correspondence. Research found in this regard that employees' perceptions of the state of the psychological contract (i.e. fulfilment of mutual expectations) explained their satisfaction with retention practices (Deas, 2017).

\section{Job embeddedness}

Employees' job embeddedness represents the collective, generally non-affective reasons why they would not leave a job or organisation. Job embeddedness presumes personenvironment correspondence and relates to how well an employee perceives himself or herself to be a good job fit in his or her current job or with the organisation, the ties (links) they have with people at work and what benefits they would have to sacrifice should they decide to leave the organisation (Mitchell et al., 2001a; Mitchell, Holtom, Lee, Sablynski, \& Erez, 2001b; Van Dyk, 2012). Seen through the theoretical lens of person-environment correspondence (Dawis, 1996), job embeddedness represents employees' psychological attachment to personally valued job characteristics and working conditions that influence their satisfaction levels. The more connections the employee has, for example, with individuals at the workplace, the more the employee is bound to the job and the organisation (Mitchell et al., 2001a, 2001b). The better the fit between employees' career development needs and expectations (i.e. career goals and future plans) and the workplace, the less likely it is that they will have the intention to leave the organisation (Holtom \& O'Niel, 2004; Mitchell et al. 2001b). The more benefits (i.e. perks, career advancement opportunities, compensation and health benefits) employees would have to give up when leaving, the more difficult it is to leave the organisation (Mitchell et al. 2001b). The link between employees' overall job embeddedness and their satisfaction with organisational retention practices reflects the principle of mutual responsiveness in the person-environment relationship. In line with previous research (Van Dyk, 2012), it was therefore expected that employees' overall job embeddedness would be positively related to their satisfaction with organisational retention practices.

\section{Workplace friendship}

Workplace friendship is an interpersonal relationship that includes shared interests and values, mutual commitment and trust between employees at a workplace (Berman, West, \& Richter, 2002; Nielsen et al., 2000). Workplace friendships develop from employees' innate psychological need for belonging and having close relationships with others (Khaleel et al., 2016). The opportunity for and prevalence of positive workplace affiliations (i.e. opportunities to communicate and work collectively with other employees within the organisation and the perception of friendships characterised by trust, confidence and a strong mutual desire to connect and interact inside and outside the workplace) are seen as aspects of person-environment correspondence (Capuzzi \& Stauffer, 2006; Jiang, 2017; Rumens, 2010). Workplace friendship has a supportive function in helping employees advance in their careers through network connections, adjust to changing workplace conditions and is a source of information including the provision of work-related resources that help employees perform better (Jiang, 2017; Mao \& Hsieh, 2012). Although research on workplace friendship is limited, preliminary research shows that employees who perceive that they work with friendly people have high job embeddedness because of the valued ties they form with people at work (Bartelli, 2006; Golden, 2007; Regts \& Mollemen, 2012). Perceived social support in the workplace has been suggested to promote person-environment fit and increase positive outcomes in career development processes (Jiang, 2017). Allen, Robbins and Casillas (2008) further found a positive link between social connectedness, job embeddedness and retention. Although the role of workplace friendship in the job embeddednessretention practices satisfaction link is unknown, it was therefore expected that employees' perceptions of workshop friendship would function as an underlying psychological mechanism in explaining this link.

\section{Career concerns}

Employees' career concerns allude to their career development needs for getting established in a job and career (i.e. fitting into the work group, developing job competencies, making career progress in the organisation), adapting to changing work and employment market conditions (i.e. upskilling, career changes for further growth and development, sustaining employability) and achieving work-life balance (i.e. adjusting one's work schedule, developing closer ties with one's community and work group and balancing work-life needs meaningfully; Coetzee, 2015, 2017). Seen through the theoretical lens of personenvironment fit theory (Dawis, 1996; Dawis \& Lofquist, 1993), employees' career concerns reflect their cognitive appraisal of their own and the organisation's responsiveness in adjusting to and addressing their evolving career development needs, expectations and aspirations in interaction with changing conditions in the work environment. The career development process is seen as the unfolding of the employees' abilities, needs and requirements in interaction with the work-life environments of the individual (Capuzzi \& Stauffer, 2006). Individuals engage in cognitive appraisals of their career development progress within the work environment and may see workplace conditions and practices as either challenging them to adjust to new expectations or as a hindrance to their career progress, which may give rise to specific career concerns.

Research shows that low levels of career concerns are related to higher levels of career satisfaction, which implies positive perceptions of person-environment correspondence (Bester, 2017; Takawira, 2017). Coetzee (2015) found that employees 


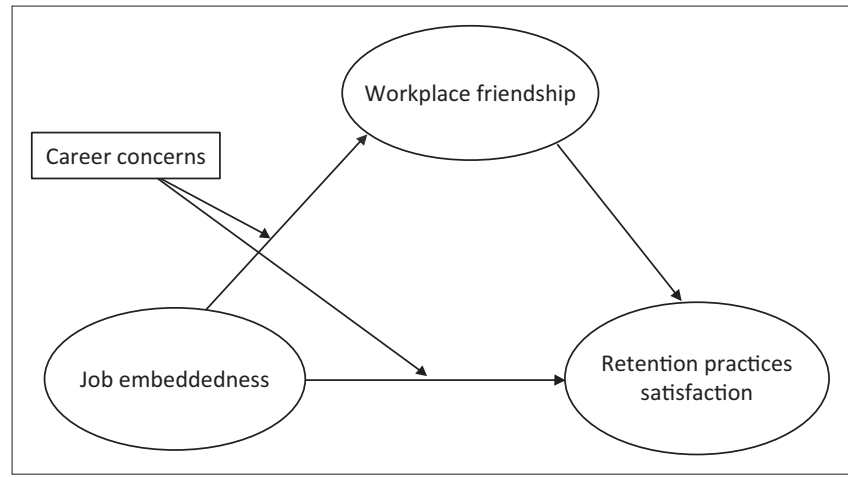

FIGURE 1: Conceptual model: Moderated-mediation effects of career concerns (moderator) and workplace friendship (mediator) on the job embeddednessretention practices satisfaction link.

with high career concerns have lower organisational commitment. Given the centrality of employees' career development satisfaction in the person-environment correspondence system (Capuzzi \& Stauffer, 2006), the present study explores employees' career concerns as a boundary condition for the indirect effect between job embeddedness and retention practices satisfaction through workplace friendship. Figure 1 illustrates the conceptual model of the research. The following is hypothesised.

Research hypothesis: Career concerns moderate the indirect effect between job embeddedness and retention practices satisfaction through workplace friendship. Specifically, the indirect effect of job embeddedness on retention practices satisfaction through workplace friendship is stronger when career concerns are low versus high, and the moderation effect occurs between (1) job embeddedness and workplace friendship and (2) job embeddedness and retention practices satisfaction.

The research hypothesis is based on the premise that employees' career concerns may either reflect positive or negative cognitive appraisals of working conditions and practices, which could influence the link between their job embeddedness and retention practices satisfaction.

\section{Research design Research approach}

This research study followed a cross-sectional quantitative research approach. Non-probability convenience sampling was used to collect primary data in a higher education institution. The retention of valuable knowledge workers in the higher education environment has become a primary concern in South Africa (Deas, 2017).

\section{Research participants}

Data were collected from a convenience sample of permanently employed staff members $(N=200 ; 58 \%$ academic level and $42 \%$ administrative staff level) within a higher education distance learning institution. The sample of participants comprised white (52\%) and black (48\%) employees. The sample was further represented by female
(60\%) and male (40\%) employees who were predominantly in their early and middle career-life stages (78\%: 26-55 years; 22\%: 56-65 years). In terms of tenure, the participants had between 1 and 10 years (53\%) and between 11 and 20 years $(47 \%)$ of service at the institution. Sixty-two per cent were married and $38 \%$ were categorised as single/widowed/ separated/divorced.

\section{Measuring instruments}

\section{Job embeddedness}

The Job Embeddedness Scale (JES), developed by Mitchell et al. (2001b), was used to measure participants' overall job embeddedness. The JES (Mitchell et al., 2001b) is a self-rated measurement and consists of 17 items measuring fit ( 7 items; e.g. 'My values are compatible with the organisation's values') and sacrifice (10 items; e.g. 'I would sacrifice a lot if I left this job'). The JES links subscale was not included in the research because it measures only the number of co-workers the individual has links with. The fit subscale measured inter alia the individuals' perceptions about the link with coworkers, which was more relevant to the research focus of the present study. Respondents were required to rate each item on a six-point Likert-type scale ( 1 = strongly disagree; 6 = strongly agree). Research by Mitchell et al. (2001b) confirms the construct validity of the JES. In terms of reliability (internal consistency), the Cronbach's alpha coefficient obtained for job embeddedness was 0.87 .

\section{Retention practices satisfaction}

The Retention Factor Measurement Scale (RFMS), developed by Döckel (2003), was used to measure respondents' overall satisfaction with organisational retention practices. The RFMS (Döckel, 2003) is a self-rated scale that consists of 39 items that measure satisfaction with six retention practices: compensation (13 items; 'On my present job this is how I feel about the company's pay structure'), job characteristics (4 items; 'The job requires me to use a number of complex or high-level skills'), training and development opportunities (6 items; 'There are enough development opportunities for me in this company'), supervisor support (6 items; 'My supervisor often lets me know how well she/he thinks I am performing on the job'), career opportunities (6 items; 'My chances for being promoted are good') and work-life balance (4 items; 'My job has negative effects on my personal life'), measured on a six-point Likert-type scale ( 1 = strongly dissatisfied; 6 = strongly satisfied). An overall Cronbach's alpha coefficient of 0.91 was obtained for overall satisfaction with retention practices. Research by Deas (2017) confirms the construct validity and reliability of the RFMS.

\section{Career concerns}

The Psychological Career Preoccupations Scale (PCPS) developed by Coetzee (2015) was used in order to measure the overall career concerns of each participant. This self-rating measure consists of 26 items measuring the following three concerns: career establishment (13 items; 'To what extent are you concerned about fitting in with others in your job 
group?'), adaptation (5 items; 'To what extent are you concerned about how your concept of your interests, talent and capabilities fit with your current job or career?') and work-life adjustment (6 items; 'To what extent are you concerned about balancing work with family responsibilities?'). Respondents were required to rate each item on a five-point Likert-type scale ( 1 = not concerned; 5 = extremely concerned). An overall Cronbach's alpha coefficient of 0.93 was obtained for participants' overall career concerns. Research by Bester (2017) confirms the construct validity and internal consistency reliability of the PCPS.

\section{Workplace friendship}

The Workplace Friendship Scale (WFS) used in this study was developed by Nielsen et al. (2000) and was used to measure the participants' overall perceptions of workplace friendship. This self-rating instrument consists of 12 questions measuring the following: friendship opportunity (6 items; 'In my organisation I have the opportunity to talk informally and visit with others') and friendship prevalence (6 items; 'Being able to see my co-workers is one reason I look forward to my job'), measured on a five-point Likert scale ( 1 = strongly disagree; $5=$ strongly agree). Research by Nielsen et al. (2000) confirms the construct validity of the WFS. An overall Cronbach's alpha coefficient of 0.89 was obtained for participants' overall perception of friendship at work.

\section{Research procedure}

The research institution's online survey facilities were utilised to collect the data from the participants. Ethical clearance and permission to conduct the research were obtained from the management of the university. Participants were invited to voluntarily participate in the research study. The online questionnaire included an informed consent form.

\section{Statistical analysis}

SAS version 9.4 (2013) software was utilised to perform the statistical analyses. Descriptive statistics (means, standard deviations [SDs] and Cronbach's alpha coefficients), bivariate (zero-order) correlations and moderated-mediation statistics were performed. The practical significance (Cohen, 1992) for interpreting the correlations $(r)$ was as follows: $r<0.10$ for a small practical effect, $r<0.30$ for a moderate practical effect and $r>0.50$ for a large practical effect. Multicollinearity concerns were set at $r>0.90$. Hypothesis testing was conducted by performing a regression-based moderated-mediation analysis using the PROCESS version 2.13 for SPSS procedure developed by Hayes (2013). The Preacher and Hayes (2008) bootstrapping procedure (bootstrap samples $=5000$ ) was applied to test the proposed conditional indirect effects outlined in the research hypothesis. Bootstrapping is a more stringent bias-correcting procedure that involves resampling and building a nonnormal sampling distribution of the indirect effect, from which confidence intervals can be constructed. This approach reduces the likelihood of type I error (Preacher \&
Hayes, 2008; Hayes, 2015). The 95\% lower confidence interval levels (LLCI) and upper confidence interval levels (ULCI) were used as the threshold for examining the significance of direct and indirect effects. Following the guidelines of Shrout and Bolger (2002), LLCI and ULCI ranges that did not include zero provided evidence of significant direct and indirect effects.

The cross-sectional research design of this study did not permit causal interferences from the data analysis ( $\mathrm{Wu} \&$ Zumbo, 2008). The research hypothesis therefore tested the magnitude of the interaction (moderation) and conditional direct and indirect effects among the variables. In order to decrease multicollinearity among the main and interaction effects, all continuous variables were mean centred before analysis (Aiken \& West, 1991). The moderated-mediation analysis also controlled for the biographical variables of race, gender, age, marital status, position and tenure as control variables because previous research suggested that these variables may influence retention practices satisfaction levels (Deas, 2017; Stoltz, 2015; Van Dyk, 2012).

\section{Ethical consideration}

Ethical clearance and permission to conduct the research were obtained from the management of the university. Participants were invited to voluntarily participate in the research study. The online questionnaire included an informed consent form. The privacy, anonymity and confidentiality of all the participants were ensured and honoured.

\section{Results \\ Descriptive statistics and correlations}

The reliability coefficients reported in Table 1 show acceptable internal consistency reliability of the four overall scales, with the coefficients for all four scales being higher than the threshold value of $>0.70$. As can be seen from Table 1 , the biographical variable of race had significant negative associations with job embeddedness, career concerns and workplace friendship. Age, position and tenure had significant negative associations with only career concerns. The correlations ranged between $r \geq-0.17$ and $r \leq-0.49$ at $p \leq$ 0.01 , a small to moderate practical effect. Job embeddedness, workplace friendship and retention practices satisfaction had no significant correlations with career concerns. The correlations between job embeddedness, workplace friendship and retention practices satisfaction ranged between $r \geq 0.38$ and $r \leq 0.68$ at $p \leq 0.001$, moderate to large practical effect. No multicollinearity concerns were detected.

\section{Testing main and interaction effects}

The first step in testing the research hypothesis was to assess the main effects of and interaction effects between job embeddedness and career concerns on explaining the variance in (1) workplace friendship and (2) retention practices satisfaction. Table 2 shows that only job 
TABLE 1: Descriptive statistics: Means, standard deviations, internal consistency reliability coefficients and zero-order correlations.

\begin{tabular}{|c|c|c|c|c|c|c|c|c|c|c|c|c|c|}
\hline Number & Variable & Mean (SD) & $\alpha$ & 1 & 2 & 3 & 4 & 5 & 6 & 7 & 8 & 9 & 10 \\
\hline 1 & Race & - & - & - & - & - & - & - & - & - & - & - & - \\
\hline 2 & Gender & - & - & - & - & - & - & - & - & - & - & - & - \\
\hline 3 & Age & - & - & - & - & - & - & - & - & - & - & - & - \\
\hline 4 & Marital status & - & - & - & - & - & - & - & - & - & - & - & - \\
\hline 5 & Position & - & - & - & - & - & - & - & - & - & - & - & - \\
\hline 6 & Tenure & - & - & - & - & - & - & - & - & - & - & - & - \\
\hline 7 & Job embeddedness & $4.44(0.87)$ & 0.87 & $-0.17 * *$ & 0.09 & 0.07 & 0.10 & -0.06 & 0.03 & - & - & - & - \\
\hline 8 & Retention practices & $3.91(0.74)$ & 0.91 & -0.05 & 0.05 & 0.11 & 0.08 & 0.13 & -0.03 & $0.68 * * *$ & - & - & - \\
\hline 9 & Career concerns & $3.33(0.91)$ & 0.93 & $-0.49 * * *$ & -0.10 & $-0.29 * * *$ & -0.05 & $-0.22 * *$ & $-0.23 * * *$ & 0.09 & -0.09 & - & - \\
\hline 10 & Workplace friendship & $3.54(0.77)$ & 0.89 & $-0.15^{*}$ & 0.06 & -0.08 & -0.10 & 0.06 & -0.08 & $0.41 * * *$ & $0.38 * * *$ & 0.04 & - \\
\hline
\end{tabular}

Source: Authors' own work

$\mathrm{SD}$, standard deviation

$N=200$

${ }^{*} p \leq 0.05 ; * * p \leq 0.01 ; * * * \leq 0.001$

TABLE 2: Moderated regression results: Interaction effects of job embeddedness and career concerns in explaining workplace friendship.

\begin{tabular}{|c|c|c|c|c|}
\hline \multirow[t]{2}{*}{ Variables } & \multicolumn{2}{|c|}{ Coefficient estimates } & \multicolumn{2}{|c|}{ Bootstrap $95 \% \mathrm{Cl}$} \\
\hline & $\beta$ & $t$ & LLCI & ULCI \\
\hline Model & - & - & - & - \\
\hline Constant & 3.50 & $24.16 *$ & 3.22 & 3.79 \\
\hline Job embeddedness (A) & 0.36 & $6.08^{*}$ & 0.25 & 0.48 \\
\hline Career concerns (B) & -0.03 & -0.40 & -0.15 & 0.10 \\
\hline Interaction term: $A \times B$ & -0.04 & -0.70 & -0.14 & 0.07 \\
\hline Race & -0.09 & -0.74 & -0.34 & 0.15 \\
\hline Gender & 0.04 & 0.35 & -0.17 & 0.24 \\
\hline Age & 0.07 & 0.54 & -0.18 & 0.31 \\
\hline Marital status & 0.18 & 1.69 & -0.03 & 0.38 \\
\hline Position & 0.10 & 0.82 & -0.13 & 0.32 \\
\hline Tenure & -0.19 & -1.54 & -0.42 & 0.05 \\
\hline Model info & - & - & - & - \\
\hline$F p=5.42 *$ & - & - & - & - \\
\hline$R^{2}=0.21$ & - & - & - & - \\
\hline
\end{tabular}

embeddedness had a significant main effect $(\beta=0.36, p=$ 0.001 , bootstrap LLCI $=0.25$; ULCI $=0.48$ ) on explaining the variance in workplace friendship. The biographical (control) variables had no main effects on workplace friendship. The interaction term (job embeddedness $\times$ career concerns) was insignificant. The moderation regression model explained $21 \%\left(R^{2}=0.21 ; F=5.42 ; p=\right.$ 0.000 ; moderate practical effect) of the variance in workplace friendship.

As shown in Table 3, both job embeddedness $(\beta=0.56$, $p=0.001$, bootstrap LLCI $=0.46 ;$ ULCI $=0.66)$ and career concerns $(\beta=-0.11, p=0.04$, bootstrap LLCI $=-0.20$; ULCI $=-0.02)$ had significant main effects in explaining the variance in retention practices satisfaction. The interaction term (job embeddedness $\times$ career concerns) was insignificant. The moderation regression model explained $52 \%\left(R^{2}=0.52 ; F=20.11 ; p=0.000 ;\right.$ large practical effect) of the variance in retention practices satisfaction. With the exception of position $(\beta=0.19, p=0.05$, bootstrap LLCI $=0.02$; ULCI $=0.36$ ), the biographical (control) variables had no main effect on retention practices satisfaction.
TABLE 3: Moderated regression results: Interaction effects of job embeddedness and career concerns in explaining retention factor satisfaction

\begin{tabular}{|c|c|c|c|c|}
\hline \multirow[t]{2}{*}{ Variables } & \multicolumn{2}{|c|}{ Coefficient estimates } & \multicolumn{2}{|c|}{ Bootstrap $95 \% \mathrm{Cl}$} \\
\hline & $\beta$ & $t$ & LLCl & ULCI \\
\hline Model & - & - & - & - \\
\hline Constant & 3.44 & $15.64 * *$ & 3.01 & 3.88 \\
\hline Workplace friendship & 0.10 & 1.88 & -0.01 & 0.21 \\
\hline Job embeddedness (A) & 0.56 & $11.38^{* *}$ & 0.46 & 0.66 \\
\hline Career concerns (B) & -0.11 & $-2.29 *$ & -0.20 & -0.02 \\
\hline Interaction term: $\mathrm{A} \times \mathrm{B}$ & 0.02 & 0.40 & -0.06 & 0.09 \\
\hline Race & -0.01 & -0.11 & -0.19 & 0.17 \\
\hline Gender & -0.02 & -0.27 & -0.18 & 0.13 \\
\hline Age & 0.07 & 0.71 & -0.12 & 0.25 \\
\hline Marital status & 0.02 & 0.21 & -0.14 & 0.17 \\
\hline Position & 0.19 & $2.21 *$ & 0.02 & 0.36 \\
\hline Tenure & -0.03 & -0.36 & -0.21 & 0.15 \\
\hline Model info & - & - & - & - \\
\hline$F p=20.11^{* *}$ & - & - & - & - \\
\hline$R^{2}=0.52$ & - & - & - & - \\
\hline
\end{tabular}

\section{Testing moderated-mediation effects}

Overall, the results provided evidence in support of the research hypothesis: career concerns moderate the indirect effect between job embeddedness and retention practices satisfaction through workplace friendship. Specifically, the indirect effect of job embeddedness on retention practices satisfaction through workplace friendship is stronger when career concerns are low versus high, and the moderation effect occurs between job embeddedness and retention practices satisfaction.

The conditional direct and indirect effects were analysed with the values of career concerns (moderator) set at the mean and plus or minus one SD from the mean. As shown in Table 4, the mean of career concerns was zero because the score was mean centred. Table 4 reveals that at all three mean score values of career concerns (moderator), the conditional direct effects of job embeddedness on retention practices satisfaction were significant (i.e. the bias-corrected bootstrap LLCI and ULCI did not include zero in the confidence interval $[\mathrm{CI}]$ values range). This implies that, although no interaction effect between job embeddedness and career 
TABLE 4: Moderated-mediation results: Direct and indirect effects.

\begin{tabular}{|c|c|c|c|c|c|c|}
\hline \multirow[t]{2}{*}{ Variables } & \multirow[t]{2}{*}{ Variables } & \multirow[t]{2}{*}{ Effect $\beta$} & \multirow[t]{2}{*}{ SE } & \multirow[t]{2}{*}{$t$} & \multicolumn{2}{|c|}{ Bootstrap 95\% Cl } \\
\hline & & & & & LLCl & ULCI \\
\hline \multicolumn{7}{|c|}{ Conditional direct effect of job embeddedness on retention practices satisfaction at the values of career concerns (moderator) } \\
\hline \multirow{3}{*}{$\begin{array}{l}\text { Values of career concerns at } \\
\text { mean (plus/minus one SD from } \\
\text { mean) }\end{array}$} & -0.90 & 0.54 & 0.06 & $9.07 *$ & 0.43 & 0.66 \\
\hline & 0.00 & 0.56 & 0.05 & $11.38^{*}$ & 0.46 & 0.66 \\
\hline & 0.90 & 0.57 & 0.06 & $9.40 *$ & 0.45 & 0.69 \\
\hline \multicolumn{7}{|c|}{ Conditional indirect effect of job embeddedness on retention practices satisfaction through workplace friendship at the values of career concerns (moderator) } \\
\hline \multirow{2}{*}{$\begin{array}{l}\text { Mediator (workplace friendship) } \\
\text { at the values of career concerns } \\
\text { (moderator) }\end{array}$} & 0.00 & 0.04 & 0.02 & - & -0.001 & 0.09 \\
\hline & 0.90 & 0.03 & 0.02 & - & -0.001 & 0.10 \\
\hline \multicolumn{7}{|c|}{ Indirect effect of workplace friendship on job embeddedness-retention practices satisfaction link } \\
\hline Mediator (workplace friendship) & - & -0.004 & 0.01 & - & -0.03 & 0.01 \\
\hline
\end{tabular}

$\mathrm{Cl}$, confidence interval; $\mathrm{LLCl}$, lower level confidence interval; ULCl, upper level confidence interval; SE, standard error; SD, standard deviation.

$N=199$.

$*, p \leq 0.001$.

concerns was detected in explaining the variance in retention practices satisfaction, the positive link between job embeddedness and retention practices satisfaction is conditional (i.e. dependent on the participants' scores - high and low - on career concerns).

Table 4 further shows that workplace friendship did not have a significant mediating effect on the job embeddednessretention practices satisfaction link $(\beta=-0.004$, bootstrap LLCI $=-0.03$; ULCI $=0.01$ ). However, low scores on career concerns also functioned as moderating mechanism when observing the link between job embeddedness and retention practices satisfaction through workplace friendship as mediator. That is, the indirect effect of job embeddedness on retention practices satisfaction through workplace friendship is conditional on low score values of career concerns: career concerns value $=-0.90 ; \beta=0.04$, bootstrap $\mathrm{LLCI}=0.001$; ULCI $=0.10$. In other words, when participants had low career concerns, the link between their job embeddedness and satisfaction with retention practices through their perceptions of workplace friendship was positive and significant.

\section{Discussion}

A central question in retention research revolves around what psychological factors drive employees to remain at an organisation. Replicating research that suggests employees' job embeddedness and satisfaction with retention practices are important factors in this question (Van Dyk, 2012), the present research added new insights into understanding the job embeddedness-retention practices satisfaction link. Seen through the theoretical lens of person-environment fit theory (Dawis, 1996; Dawis \& Lofquist, 1993), the results help illuminate the psychological process of workplace friendship underlying the job embeddedness-retention practices satisfaction link, as well as the boundary conditions of this process as set by participants' career concerns.

The results indicated that the participants' career concerns moderated the indirect effect between job embeddedness and retention practices satisfaction through workplace friendship. Although job embeddedness had a significant main effect on retention practices satisfaction, the job embeddednessretention practices satisfaction link was also significant at low and high scores of participants' career concerns. Low career concerns had also a significant main effect on higher levels of retention practices satisfaction.

Person-environment fit theory (Dawis, 1996; Dawis \& Lofquist, 1993) posits that employees' needs are primary in their influence on fit, and perceived correspondence between the employee and work environment leads to satisfaction. The positive link between job embeddedness and retention practices satisfaction could be attributed to the premise that employees' job embeddedness is a consequence of perceived positive forces that strengthen the correspondence between the employee and the work environment. Employees often value developing close ties with co-workers and workgroups (links), are usually pleased to find jobs that are compatible with their goals and values (fit) and that provide desirable perks (sacrifice), all of which influence their satisfaction levels (Ng \& Feldman, 2009; Van Dyk, 2012).

The results suggest that the positive link between employees' job embeddedness and their satisfaction with organisational retention practices is dependent on the strength of their career concerns. The conditional effect of participants' career concerns in the job embeddedness-retention practices satisfaction link could be attributed to the premise of personenvironment fit theory (Dawis, 1996) that the employeeenvironment relationship is one of mutual responsiveness. The interactive process between the employee and the organisation is characterised by ongoing and ever-changing adjustment from both sides (Dawis, 1996). Organisations introduce and revise certain human resource practices that support the job embeddedness and retention of valuable employees, while employees' self-concept and career development needs evolve and change over time, which influences their satisfaction with work environment conditions (Döckel, 2003; Stoltz, 2015). Employees' career concerns allude to their preoccupations with adjusting to the work environment in order to maintain person-environment correspondence. Career concerns relate to their career development needs for getting established and making 
progress in a job and adapting to changing work and employment market conditions, which involves sustaining their employability and marketability through upskilling and career advancement and finding meaningful work-life balance based on changing needs (Coetzee, 2015, 2017). According to person-environment fit theory, both the employee and work environment are subject to change and will therefore influence each other (Capuzzi \& Stauffer, 2006; Dawis, 1996). This premise suggests that while it is known that employees' career concerns change over time as the selfconcept evolves (Super, 1996), so may their satisfaction with work environment conditions and practices also change. Organisations can therefore not only rely on strengthening employees' job embeddedness to enhance their satisfaction but should also take note of the changing career development needs of their employees and adjust their retention practices accordingly.

An interesting finding is that workplace friendship had no direct effect on retention practices satisfaction and did not directly mediate the job embeddedness-retention practices satisfaction link. This finding is contrary to previous research indicating workplace friendship as an important social support mechanism in employees' career development, job success and satisfaction, job embeddedness and perceived person-environment fit (Bader, Hashim, \& Zaharim, 2013; Jiang, 2017; Rumens, 2010). It was therefore expected that in line with previous research, workplace friendship would explain the positive link between job embeddedness and satisfaction with retention practices. However, workplace friendship had a conditional indirect effect when participants' career concerns were low. Specifically, when participants had low career concerns, the link between their job embeddedness and satisfaction with retention practices through their perceptions of workplace friendship was positive and significant. The findings suggest that participants' career concerns served as important boundary conditions for the psychological mediating process of workplace friendship in the job embeddedness-retention practices satisfaction link. The findings corroborate the premise of person-environment fit theory that the unfolding of employees' career development process is central to the interaction between the person and the work environment, which may explain the boundary conditions of career concerns on the mediating effect of workplace friendship (Capuzzi \& Stauffer, 2006; Dawis, 1996).

\section{Practical implications}

The centrality of employees' career development needs and resultant preoccupations in the job embeddedness-retention practices satisfaction link has implications for organisational retention practices. Managers and practitioners should ensure that they frequently review employees' career concerns through formal career discussions. Such discussions should evaluate the relevance of current retention practices and their suitability for addressing the career development needs and concerns of employees. An evaluation of employees' sense of job embeddedness (i.e. the forces and conditions that tie them to their jobs) and their current satisfaction levels with organisational retention practices may be a valuable exercise. Enhancing work conditions and practices to support the evolving career development needs of valuable employees may be key to maintaining personenvironment correspondence and retaining them.

\section{Research limitations and directions for future research}

Several limitations need to be noted in the interpretation of the results. Firstly, owing to the cross-sectional design of the research, no cause-effect relations could be established. Longitudinal studies are recommended to establish the conditional effects of career concerns in the job embeddedness-retention practices satisfaction link through the psychological process of workplace friendship. Secondly, owing to the sample characteristics, the results cannot be generalised to other occupational and demographical settings. It is thus recommended to replicate this study with a larger sample and within other industries as well. Thirdly, the study is regarded as a preliminary, exploratory study because it utilised only the overall scores of the measuring instruments. Future research could replicate the study by utilising the subscales in analysing the psychological processes and boundary conditions of the processes influencing the job embeddedness-retention practices satisfaction link. Finally, the use of self-report measures could potentially have made the findings vulnerable to common-method bias. However, the effects of commonmethod variance were minimised by ensuring the anonymity and confidentiality of the responses.

\section{Conclusion}

This study contributed new knowledge to contemporary retention theory by providing new evidence of the important role of employees' career development needs in retention practice. Seen through the theoretical lens of personenvironment fit theory, the findings added new insights into the circumstances under which employees' job embeddedness positively influences their satisfaction with organisational retention practices. Addressing employees' career concerns may hold the key to strengthening the link between their job embeddedness and satisfaction with organisational retention practices. It is trusted that this research will inspire further research on the topic, which is of current importance for both the organisation and the employee.

\section{Acknowledgements Competing interests}

The authors declare that they have no financial or personal relationships that may have inappropriately influenced them in writing this article. 


\section{Authors' contributions}

I.L.P. and N.F. coordinated the data collection. M.C. assisted with the data analysis and interpretation. I.L.P., M.C. and N.F. all made major contributions to the conceptual framework and writing of the research article.

\section{References}

Aiken, L.S., \& West, S.G. (1991). Multiple regression: Testing and interpreting interactions. Newbury Park, CA: Sage.

Allen, J., Robbins, S.B., \& Casillas, A. (2008). Third-year college retention and transfer: Effects of academic performance, motivation and social connectedness. Research in Higher Education, 49(7), 647-664. https://doi.org/10.1007/s11162-008-9098-3

Asgharian, R., Yusoff, R., YaserMazhari, A.M., \& HazratSoltan, E.K. (2013). Examining the effect of workplace friendships and job embeddedness on turnover intention (The Case of Mashhad as a Tourist Destination in Iran). International Journal of Business and Management Invention, 2(7), 17-25.

Bader, H.A.M., Hashim, I.H.M., \& Zaharim, N.M. (2013). Workplace friendship among bank employees in Eastern Libya. Digest of Middle East Studies, 22(1), 94-116. https://doi.org/10.1111/dome.12020

Bartelli, A.M. (2006). Determinants of bureaucratic turnover intention: Evidence from the Department of the Treasury. Journal of Public Administration Research and Theory, 17, 235-258.

Bayes, J., \& Kelly, R.M. (1994). Managing sexual harassment in public employment. Public Personnel Administration: Problems and Perspectives, 3, 217-231. https:// doi.org/10.1093/jopart/mul003

Berman, E.M., West, J.P., \& Richter, J.M.N. (2002). Workplace relations: Friendship patterns and consequences (according to managers). Public Administration Review, 62(2), 217-230. https://doi.org/10.1111/0033-3352.00172

Bester, S.M. (2017). Toward constructing a psychosocial model of career wellbeing for the South African working adult. Unpublished doctoral thesis, University of South Africa, Pretoria, South Africa.

Capuzzi, D. \& Stauffer, M.D. (2006). Career counseling: Foundations, perspectives and applications. New York, NY: Pearson.

Coetzee, M. (2015). Employees' psychosocial career preoccupations in relation to their work-related commitment. Southern African Business Review, 19(3), 30-47.

Coetzee, M. (2017). Psycho-social career preoccupations and employability capacities in the work context. In M. Tomlinson \& L. Holmes (Eds.), Graduate employability in context: Research, theory and debate (pp. 295-316). London: Palgrave MacMillan.

Cohen, J. (1992). Quantitative methods in psychology: A power primer. Psychological Bulletin, 112(1), 153-159. https://doi.org/10.1037/0033-2909.112.1.155

Dawis, R.V. (1996). The theory of work adjustment and person-environment correspondence counseling. In D. Brown, et al., (Eds.), Career choice and
development: Applying contemporary theories to practice. 3rd edn., pp. 75-120. development: Applying contempord
San Francisco, CA: Jossey-Bass.

Dawis, R.V. \& Lofquist, L.H. (1993). From TWA to PEC. Journal of Vocational Behavior, 43, 113-121. https://doi.org/10.1006/jvbe.1993.1037

Deas, A.J. (2017). Constructing a psychological retention profile for diverse generational groups in the higher educational environment. Unpublished doctoral thesis, University of South Africa, Pretoria, South Africa.

Döckel, A. (2003). The effect of retention factors on organisational commitment: An investigation of high technology employees. Unpublished master's thesis, University of Pretoria, Pretoria.

Döckel, A., Basson, J.S., \& Coetzee, M. (2006). The effect of retention factors on organizational commitment: An investigation of high technology employees. South African Journal of Human Resource Management, 4(2), 20-28. https://doi. org/10.4102/sajhrm.v4i2.91

Erasmus, B.J., Grobler, A., \& Van Niekerk, M. (2015). Employee retention in higher education institution: An organisational development perspective. Progressio, 37(2), 33-63. https://doi.org/10.25159/0256-8853/600

Golden, T. (2007). Co-workers who telework and the impact on those in the office: Understanding the implications of virtual work for co-worker satisfaction and turnover intentions. Human Relations, 60(11), 1641-1667. https://doi.org/ $10.1177 / 0018726707084303$

Hayes, A.F. (2013). Introduction to mediation, moderation, and conditional process analysis: A regression-based approach. New York, NY: The Guilford Press.

Hayes, A.F. (2015). An index and test of linear moderated mediation. Multivariate Behavioral Research, 50(1), 1-22. https://doi.org/10.1080/00273171.2014.962683
Holtom, B.C., \& O'Niel, B.S. (2004). Job embeddedness: A theoretical foundation for developing a comprehensive nurse retention plan. Journal of Nursing Administration 34(5), 216-227. https://doi.org/10.1097/00005110-200405000-00005

Jiang, Z. (2017). Social support and career psychological states: An integrative model of person-environment fit. Journal of Career Assessment, 25(2), 219-237. https://doi. org/10.1177/1069072715621019

Johnson, A., Sachau, D. \& Englert, D. (2010). Organizational and occupational embeddedness of federal law enforcement personnel. Journal of Police and Criminal Psychology, 25(2), 75-89. https://doi.org/10.1007/s11896-009-9063-x

Khaleel, M., Chelliah, S., Khalid, J., Jamil, M., \& Manzoor, F. (2016). Employee engagement as an outcome of friendship at workplace: Moderating role of job embeddedness. International Journal of Academic Research in Business and Socia Sciences, 6(6), 1-6. https://doi.org/10.6007/IJARBSS/v6-i6/2171

Kim, W. (2017). Examining mediating effects of work engagement among job resources, job performance and turnover intention. Performance Improvement Quarterly, 29(4), 407-425. https://doi.org/10.1002/piq.21235

Lee, T.W., Mitchell, T.R., Sablynski, C.J., Burton, J.P. \& Holtom, B.C. (2004). The effects of job embeddedness on organizational citizenship, job performance, volitional absences, and voluntary turnover. Academy of Management Journal, 47(5), 711-722. https://doi.org/10.2307/20159613

Mao, H.Y. \& Hsieh, A.T. (2012). Organizational level and friendship expectation at work. Asian Business \& Management, 11(4), 485-506. https://doi.org/10.1057/ abm.2012.14

Mitchell, T.R., Holtom, B.C. \& Lee, T.W. (2001a). How to keep your best employees: Developing an effective retention policy. Academy of Management Executive, Developing an effective retention policy. Academy of Ma
15(4), 96-108. https://doi.org/10.5465/AME.2001.5897929

Mitchell, T.R., Holtom, B.C., Lee, T.W., Sablynski, C.J., \& Erez, M. (2001b). Why people stay: Using job embeddedness to predict voluntary turnover: Academy of Management Journal, 44(6), 1102-1121. https://doi.org/10.2307/3069391

Netswera, F.G., Rankhumise, E.M., \& Mavundla, T.R. (2005). Employee retention factors for South African higher education institutions: A case study. South African Journal of Human Resource Management, 3(2), 36-40. https://doi.org/10.4102/ sajhrm.v3i2.64

$\mathrm{Ng}$, T.W.H. \& Feldman, D.C. (2009). Occupational embeddedness and job performance. Journal of Organizational Behavior, 30, 863-891. https://doi.org/10.1002/job.580

Nielsen, I.K., Jex, S., \& Adams, G.A. (2000). Development and validation of scores on a two-dimensional workplace friendship scale. Educational and Psychological Measurement, 60(4), 628-643. https://doi.org/10.1177/00131640021970655

Paul, E.F. (1994). Sexual harassment: A defining moment and its repercussions. The Politics of Problem Definition: Shaping the Policy Agenda, 1, 67-97.

Preacher, K.J., \& Hayes, A.F. (2008). Asymptotic and resampling strategies for assessing and comparing indirect effects in multiple mediator models. Behavior Research Methods, 40, 879-891. https://doi.org/10.3758/BRM.40.3.879

Regts, G., \& Molleman, E. (2012). To leave or not to leave. When received interpersonal citizenship behavior influences an employee's turnover intention. Human Relations, 66(2), 193-218. https://doi.org/10.1177/0018726712454311

Riordan, C.M., \& Griffethc, R. W (1995). The opportunity for friendship in the workplace: An underexplored construct. Journal of Business and Psychology 10, 141-154. https://doi.org/10.1007/BF02249575

Rumens, N. (2010). Firm friends: Exploring the supportive components in gay men's workplace friendships. The Sociological Review, 58(3), 135-155. https://doi. org/10.1111/j.1467-954X.2009.01879.x

Samuel, M.O., \& Chipunza, C. (2009). Employee retention and turnover: Using motivational variables as a panacea. African Journal of Business Management, 3(8), 317-337.

SAS Institute. (2013). What's new in SAS ${ }^{\circledast}$. Cary, NC: SAS Institute Inc.

Shrout, P.E., \& Bolger, N. (2002). Mediation in experimental and nonexperimental studies: New procedures and recommendations. Psychological Methods, 7(4), 422-445. https://doi.org/10.1037/1082-989X.7.4.422

Stoltz, E. (2015). Employability attributes and career adaptability as predictors of staff satisfaction with retention factors. Unpublished master's dissertation, University of South Africa, Pretoria.

Super, D.E. (1990). A life-span, life-space approach to career development. In D. Brown $\&$ L. Brooks (Eds.), Career choice and development (2nd ed., pp. 197-261) San Francisco, CA: Jossey-Bass.

Takawira, N. (2017). Constructing a psychosocial profile for enhancing the career success of South African professional women. Unpublished doctoral thesis, University of South Africa, Pretoria, South Africa.

Van Dyk, J. (2012). The relationship between organisational commitment, retention factors and perceived job embeddedness. Unpublished master's dissertation, University of South Africa, Pretoria, South Africa.

Wu, A.D., \& Zumbo, B.D. (2008). Understanding and using mediators and moderators. Social Indicators Research, 87, 367-392. https://doi.org/10.1007/s11205-007-9143-1 